\title{
Needless Photographic Failures
}

\section{Author(s): John L. Ridgway}

Source: The Condor, Vol. 39, No. 1 (Jan. - Feb., 1937), pp. 10-12

Published by: Oxford University Press

Stable URL: https://www.jstor.org/stable/1363480

Accessed: 08-11-2019 21:28 UTC

JSTOR is a not-for-profit service that helps scholars, researchers, and students discover, use, and build upon a wide range of content in a trusted digital archive. We use information technology and tools to increase productivity and facilitate new forms of scholarship. For more information about JSTOR, please contact support@jstor.org.

Your use of the JSTOR archive indicates your acceptance of the Terms \& Conditions of Use, available at https://about.jstor.org/terms 
pine to pine, but always in formation and always in even numbers. Only once did I see a gang of five, or any other number not comprised of pairs.

In spring, I am told, the pair hunts up a woodpecker hole in some tall dead pine and performs its racial duty in temporary isolation. But what woodpecker excavates a hole large enough? The Guacamaja (as the natives euphoniously call the parrot) is big as a pigeon, and hardly to be squeezed into a flicker-loft. Does he, with his own powerful beak, perform the necessary enlargement? Or is he dependent on the holes of the Imperial Woodpecker, which is said to occur in these parts? To some future ornithological visitor I bequeath the pleasant task of discovering the answer.

I do not know whether the nesting pairs are as noisy as these roistering flocks which greeted me in September. I do know that in September, if there are parrots on the mountain, you will soon know it. As a proper ornithologist, I should doubtless try to describe the call. It superficially resembles that of the Piñon Jay, but the music of the piñoneros is soft and nostalgic as the haze hanging in their native canyons, while that of the Guacamaja is louder and full of the salty enthusiasm of high comedy.

I am told that after the acorns ripen, they are attacked by the parrots with as much zest as the pine seeds are earlier. The occasional wanderings of parrots across the border, recorded by Florence Bailey (Birds of New Mexico, pp. 306-307), are doubtless motivated by the search for mast.

One cannot help but wonder what the good roads program now impending throughout Mexico will do for, or to, this species. It does not have a large range; Bailey says only the northern Sierras. I can only hope that Mexico. will find ways so far unfound by us to use these mountains without destroying them.

Division of Game Management, University of Wisconsin, Madison, Wisconsin, October 6, 1936 .

\section{NEEDLESS PHOTOGRAPHIC FAILURES}

\section{By JOHN L. RIDGWAY}

The writer's close attention has frequently been directed to a lack of definition in certain half-tone reproductions of photographs appearing in The Condor, as well as in many other well-known and widely-distributed scientific publications, while the same volumes often contained beautiful examples of this universally used process of engraving. In calling attention to this rather common variation in quality of print, it is realized that the defects were probably as well known to the editors, and to the authors of the papers themselves, as they were to the present writer. However, he may be permitted to suggest methods which, if adopted, would do much to relieve this condition. Granting the undisputed fact that a loss of some clearness may usually be expected in a half-tone print, a successful cut depends upon a good photograph, or one well retouched, and on suitable paper and careful press work. The failure of many good half-tone cuts to meet requirements is often due to these factors alone; but more often it may be charged to the original photographs which lack the qualities needed to reproduce well.

The popular estimate of photography, compared with every other kind of picturemaking, is that it should represent the acme of truthfulness; but, unfortunately, it does not always bear out this desirable standard. The term "photographically correct" is apt to carry with it a feeling of dependable accuracy far beyond that of a mere 
drawing, which to greater or less degree must bespeak individual interpretation. That feeling of dependability carries with it the thought that anything photographed must necessarily register its reflection on the sensitive film exactly as the object presented itself in that direction at time of exposure. But there are many details in connection with an exposure that make or mar a true picture. Among them are focusing, lighting, and timing. These three elements, as everyone knows, must be right, and if they are not right the developed print may not be a true or satisfactory image of the subject.

Furthermore, some objects do not photograph well because of color and shadow effects, and authors interested in certain details of specimens doubtless find that their photographs sometimes give absolutely false effects, effects which, if not corrected, mislead. For example, a photograph of a specimen may show a light area where a shadow should appear, due possibly to reflected light; and shadows sometimes obliterate important details. Shadows may also cause an opposite interpretation of form, especially as to the third dimensional aspect, or what we usually term "relief." Sometimes defects are caused by interference of non-essential parts, that is, by objects that overlap and obstruct full vision; and there are many other accidental and unavoidable characteristics that affect the visibility of a subject when photographed.

The photographs we see reproduced are as a rule selected from those already made; that is, they are not always made for the express purpose for which they are to be used. Hence they represent snapshots taken here and there, sometimes for record; and snapshots after all are usually "chance" shots. Therefore, even if the subject has pertinent value as an illustration, the photograph may not be a good one because of failure at one or more of the points mentioned. As a result, we see photographs used as illustrations that are out of focus, and thus lack sharpness of details, photographs that are over- or under-exposed, and in which the lighting was unfavorable, not to mention photographs with interferences and other obliterative or obtrusive effects that either shut out or confuse details.

It is to the half-tones made from such faulty photographs that one's attention is directed with no little wonder that the latter had not been improved before engraving. Curiously, the eye is apt to dwell upon that which displeases rather than upon that which is faultless - a characteristic exemplified in glancing through proof sheets in which a slight imperfection is quickly detected; and worse than all, some people look only for defects and pass the perfect as a matter of course.

It is well known that some scientific writers do not countenance the retouching of photographs in any manner whatsoever as a legitimate means of illustrating scientific subjects. Ordinarily, and unless it is done well, retouching is unsatisfactory, especially when opaque pigment is used so that parts are covered instead of merely being intensified. When retouching is done in a proper manner there should be no deviation from nature and the results should show a sufficient improvement in the half-tones to fully compensate any author. In many photographic prints, faint tones and indistinct details can be strengthened without encroachment on, or altering of, other features. Parts may be put in focus, and detracting, confusing, and non-essential details can be eliminated without falsification of scientific fact. In short, a poor photograph, if on the right kind of paper, can generally be greatly improved by expert retouching through simply strengthening with an $\mathrm{F}$ or $\mathrm{B}$ pencil the parts that are very faintly shown, and eliminating parts not wanted by scraping them out and restoring the area. The resulting cut will always show a corresponding improvement in clearness and general effect. The photograph should be either an "azo" or "velox" print and should be unglazed. 
Better to demonstrate the false premises taken by many objectors to the retouching of photographs, it might be mentioned that one of our great observatories found that many photographs, particularly those of nebulae and some of the more remote planets, did not reproduce well. The photographs were sufficient in themselves, but certain of the fainter tone qualities did not show in reproduction. These were carefully strengthened and in some instances the entire picture was copied in such a way that every tone of the original would reproduce satisfactorily. These methods were so severely criticized that they were abandoned. The objection was based on the theory that each minute granule of graphite or pigment would represent, especially in case of the nebular drawing, such vast objects that the adoption of such a method would be absurd. This view was heedless of the fact that every picture, whether drawing, painting, or photograph, is a jumble of pigment. Yet, in point of fact, the work of the artist in this particular instance insured half-tone results that would embody a complete and true image of the subject without any personal equation whatever. The point, however, in stating this incident is that the retouching (or drawing) was made only to aid reproduction and produce a half-tone cut that would show the subject with more complete distinctness than in its original form by bringing out parts that would reproduce and thus offer a better interpretation of the phenomena. Other specialists, less prejudiced, agreed it would have done exactly that, and with complete success.

The writer has no special interest in offering these comments other than his interest in the general subject of scientific illustrations. This latter has naturally drawn his attention to the defects discussed in this article and has led to mild astonishment that so many pictures are used without first having been expertly worked over and improved before they were engraved. Who has been so fortunate as to have a manuscript critically read without suggestions for improvement? Why not also be critical with photographic copy which, if well prepared and well reproduced, will tell its own story even more directly than words. In the final analysis a good photographic reproduction should be a pictorial and graphic expression and as such might well be subject to revision in a manner somewhat similar to that accorded text material.

California Institute of Technology, Pasadena, September I6, I936.

\section{A PLEISTOCENE RECORD OF THE PASSENGER PIGEON IN CALIFORNIA}

WITH ONE ILLUSTRATION

\section{By HILDEGARDE HOWARD}

Rancho La Brea, that apparently never-ending source of information concerning the Pleistocene bird life of southern California, has yielded another important record. Six bones, representing four skeletal elements, are now identified as Ectopistes migratorius, the Passenger Pigeon. Though these bones have been in the Los Angeles Museum collections for years, their importance had somehow escaped notice until recently. Most of them, together with two specimens of Columba fasciata, had been put away labelled "pigeon." Not until two additional elements were recently found among some miscellaneous bones in the collection, were the specimens carefully studied and their significance noted. At this time comparisons were made with Columba fasciata, Columba flavirostris, and Melopelia asiatica as well as with Ectopistes 